\title{
Angle Class II malocclusion treated with extraction of permanent teeth
}

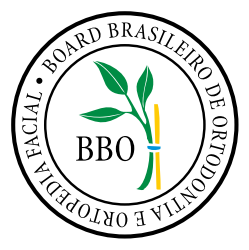

\author{
Gustavo Mattos Barreto ${ }^{1}$
}

Angle Class II malocclusion associated with anterior open bite in adult patients demands a carefully elaborated orthodontic planning, aiming at restoring not only harmonious dental and facial esthetics, but also a balanced masticatory function. Orthognathic surgery or permanent teeth extraction are often the choice of treatment, therefore, treatment decision is related to all dental, skeletal and functional aspects. The present report discusses orthodontic compensation carried out by means of upper premolar extraction performed to correct the Class II canine relationship and, consequently, the anterior open bite, accepting that the upper incisors be retroclined. This clinical case was presented to the Brazilian Board of Orthodontics and Dentofacial Orthopedics (BBO) as part of the requirements for obtaining the BBO Certification.

Keywords: Class II malocclusion. Anterior open bite. Orthodontic compensation.

A má oclusão Classe II de Angle associada à mordida aberta anterior, em pacientes adultos, envolve um planejamento ortodôntico bem elaborado e cuidadoso, tendo como objetivo principal devolver a estética facial e dentária harmoniosa, e uma função mastigatória equilibrada. O tratamento, muitas vezes, está no limite para cirurgia ortognática ou para extrações de dentes permanentes, fazendo com que a decisão esteja ligada a todos os aspectos dentários, esqueléticos e funcionais. O presente relato mostra a compensação ortodôntica por meio de extrações de pré-molares superiores, a fim de corrigir a relação de Classe II dos caninos e, consequentemente, a mordida aberta anterior, aceitando que os incisivos superiores estejam retroinclinados. Esse caso clínico foi apresentado à diretoria do Board Brasileiro de Ortodontia e Ortopedia Facial (BBO) como parte dos requisitos para a obtenção do título de Diplomado pelo BBO.

Palavras-chave: Má oclusão Classe II. Mordida aberta anterior. Compensação ortodôntica. Planejamento ortodôntico.

\section{INTRODUCTION}

A 17.11-year-old female patient came to the clinic reporting difficulty in gripping food with her front teeth and dissatisfaction regarding dental esthetics, particularly concerning her smile. In the anamnesis, the patient presented history of mouth breathing, with adenoids treated during childhood, allergic rhinitis, good oral health with few restorations, lingual interposition and absence of the third molars which had already been extracted.

\footnotetext{
${ }^{1}$ Specialist in Radiology, UNICAMP. MSc and PhD in Orthodontics and Facial Orthopedics, State University of São Paulo - Araraquara. Certified by the Brazilian Board of Orthodontics and Dentofacial Orthopedics (BBO). Visiting professor at the PostGraduate Course in Orthodontics, UNIT.

* Clinical case, category 2, accepted by the Brazilian Board of Orthodontics and Dentofacial Orthopedics, BBO.
}

How to cite this article: Barreto GM. Angle Class II malocclusion treated with extraction of permanent teeth. Dental Press J Orthod. 2013 JulyAug;18(4):126-33.

\section{DIAGNOSIS}

On assessing the patient's face, a dolichofacial pattern was observed in addition to absence of passive lip seal, increased lower facial third, significative exposure of the lower lip vermilion, wide buccal corridor when smiling, straight profile, normal upper and lower lips and increased nasolabial angle (Fig 1).

Clinically, the dental arches presented Angle Class II, division 1 malocclusion with greater magnitude on the right side (full), being cusp-to-cusp on the left side.

\footnotetext{
» The author reports no commercial, proprietary or financial interest in the products or companies described in this article.

» The patient displayed in this article previously approved the use of her facial and intraoral photographs.
}

Submitted: May 10, 2013 - Revised and accepted: May 29, 2013

Contact address: Gustavo Mattos Barreto

Rua Campo do Brito, 47 - Apt. 1002 - Edf. Mansão Cristal - Bairro 13 de Julho CEP: 49.020-380 - Aracaju/SE - Brazil

E-mail: gustavobarreto@ortos-se.com.br 

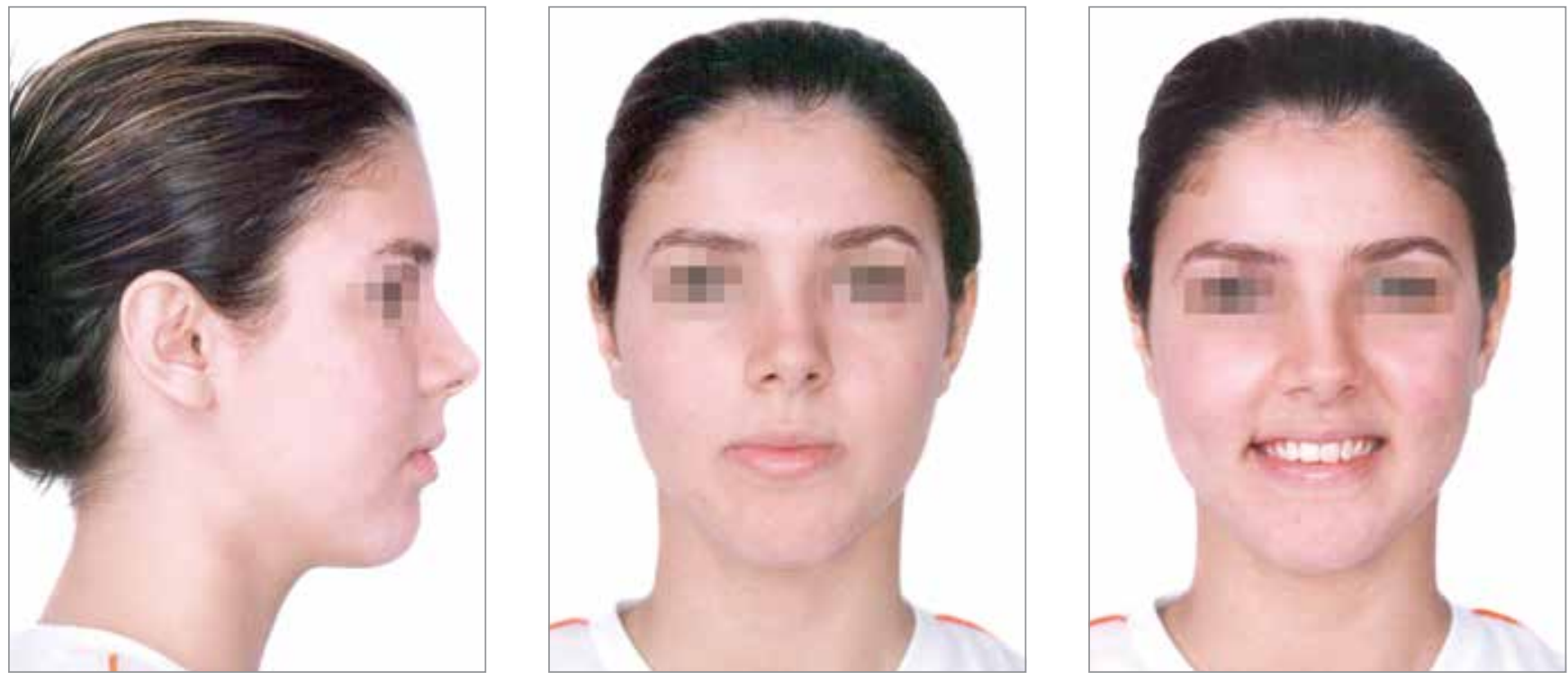

Figure 1 - Initial facial photographs.

Therefore, severe anterior open bite, restricted from canine to canine, was also observed in addition to a 2 $\mathrm{mm}$ deviation of the lower midline to the right, overjet of $8 \mathrm{~mm}$ and lingual inclination of the posterior teeth. With regard to interdental distances, the upper intercanine distance was of $30.5 \mathrm{~mm}$ while the lower one was of $27 \mathrm{~mm}$. Functional guides were absent and there was difficulty in gripping food by the anterior region (Figs 2 and 3).

The maxillomandibular relationship was within the range of normality $\left(\mathrm{ANB}=3^{\circ}\right)$, however, with both the maxilla and the mandible retruded in relation to the cranial base. $\mathrm{SNA}=75^{\circ}$ and $\mathrm{SNB}=72^{\circ}$, with a vertical growth pattern $\left(\mathrm{SN} \cdot \mathrm{GoGn}=45^{\circ}, \mathrm{FMA}=36^{\circ}\right.$ and $\mathrm{Y}$ axis $\left.=66^{\circ}\right)$. Moreover, the patient presented buccal inclination and protrusion of the upper incisors $\left(1 . \mathrm{NA}=35.5^{\circ}\right.$ and $1-\mathrm{NA}$ $=9 \mathrm{~mm})$. Additionally, she presented retroclination of lower incisors $\left(1 . \mathrm{NB}=16^{\circ}\right.$ and IMPA $\left.=76^{\circ}\right)($ Fig 4 and Table 1). On assessing the panoramic radiograph, absence of the third molars which had already been removed, and slight root shortening of teeth \#11, \#12, \#21, \#22 and apical rounding of teeth \#33, \#32, \#31, \#41, \#42 and \#43 (Fig 5) were observed.

\section{TREATMENT PLAN}

Two treatment plans were elaborated. The first one involved orthognathic surgery and was immediately discarded by the patient as well as by her parents. The second one involved extraction of the upper first premolars.
With regard to the latter, parents were aware that it would take longer, with the possibility of slight upper lip retraction. Moreover, in this planning, the upper first premolars would remain in Class II relationship, but with the canines in key of occlusion. ${ }^{1,2}$ For the correction of the anterior open bite, the space left after the extractions would allow retroclination to be planned and consequent extrusion of the upper incisors, favoring bite closure. ${ }^{3,4}$ As for arch atresia, expansion performed with a Haas appliance was recommended. Treatment prognosis would be favorable, but careful, in order to slightly maintain or change the upper lip position due to retraction. Additionally, speech monitoring would be necessary due to lingual interposition. With regard to stability, it is important to consider the removal of the etiologic factor of the anterior open bite (lingual interposition after mouth breathing during childhood). ${ }^{5}$ Occlusal adjustments were also planned after treatment finishing.

\section{PERFORMED TREATMENT}

Initially, the Haas expander appliance was installed for upper expansion. It was activated at $1 / 4$ of a turn every 12 hours, during 12 days, with a retention period lasting for five months. Afterwards, a $0.022 \times 0.028$-in Edgewise standard system conventional fixed appliance was installed, however, not including teeth \#14 and \#24, which would be removed. The extraction of teeth \#14 and \#24 was requested and a $0.9 \mathrm{~mm}$ palatal 

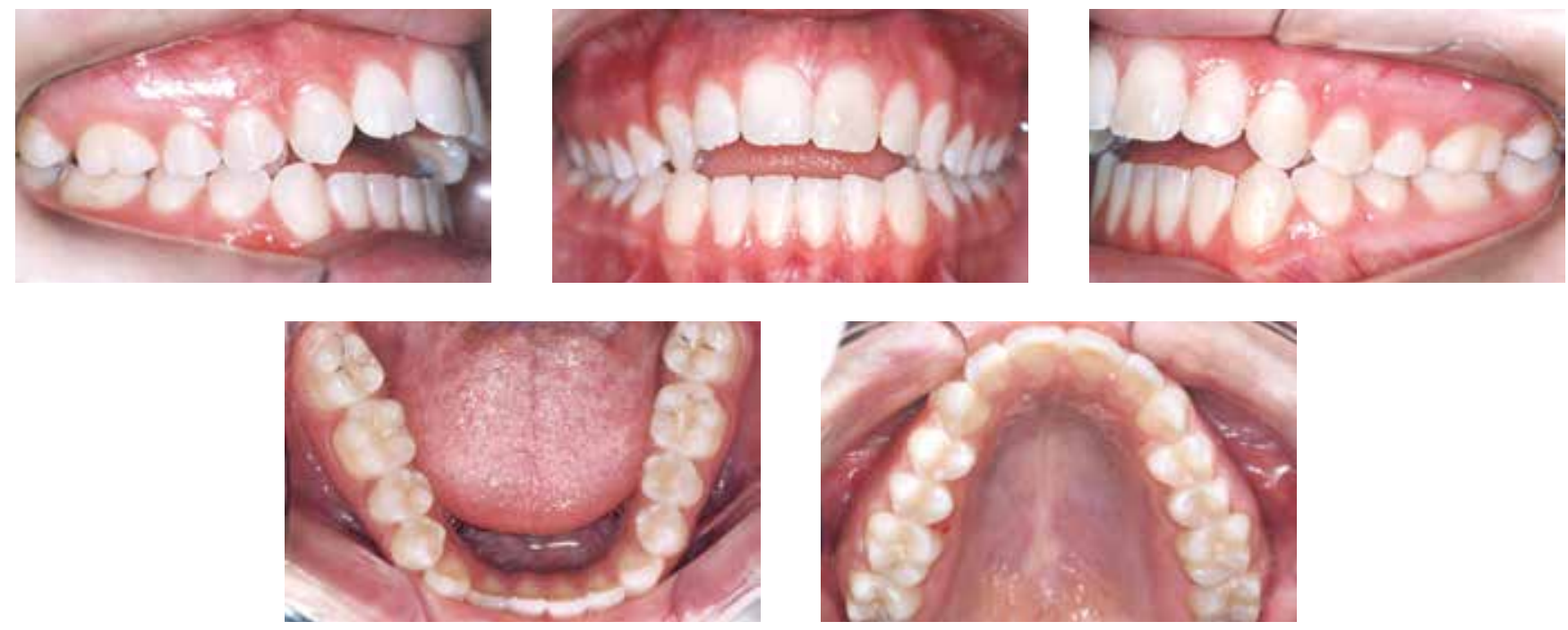

Figure 2 - Initial intraoral photographs
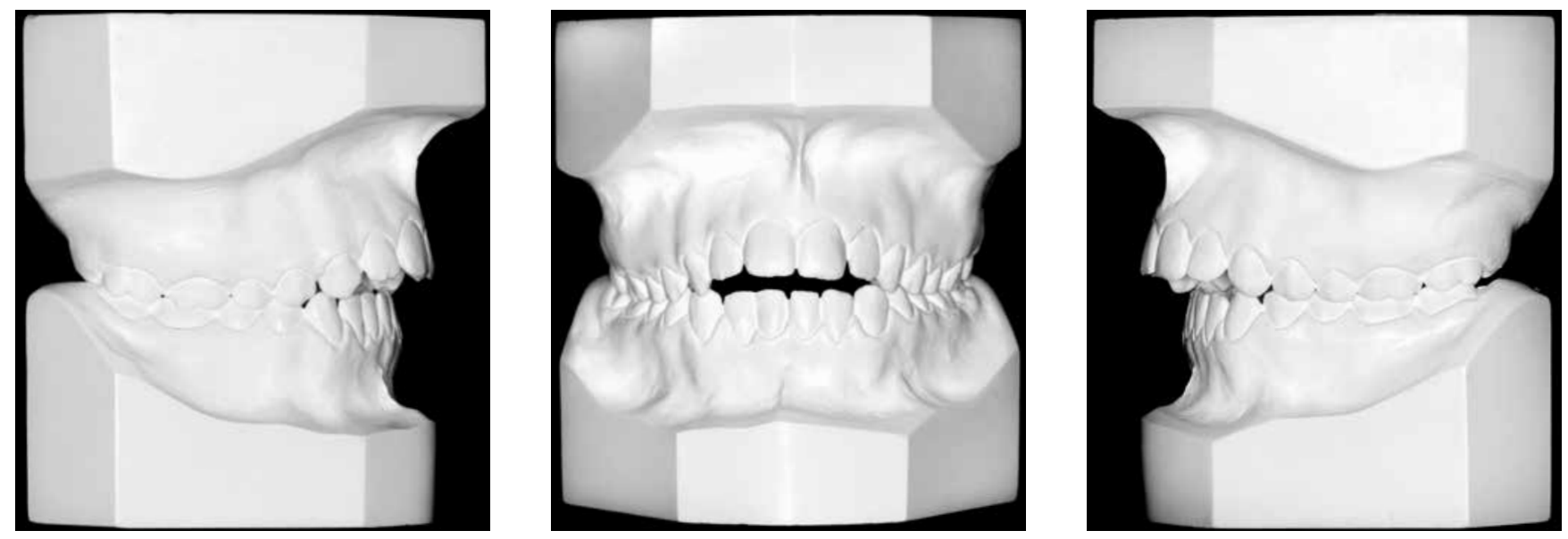

Figure 3 - Initial casts.
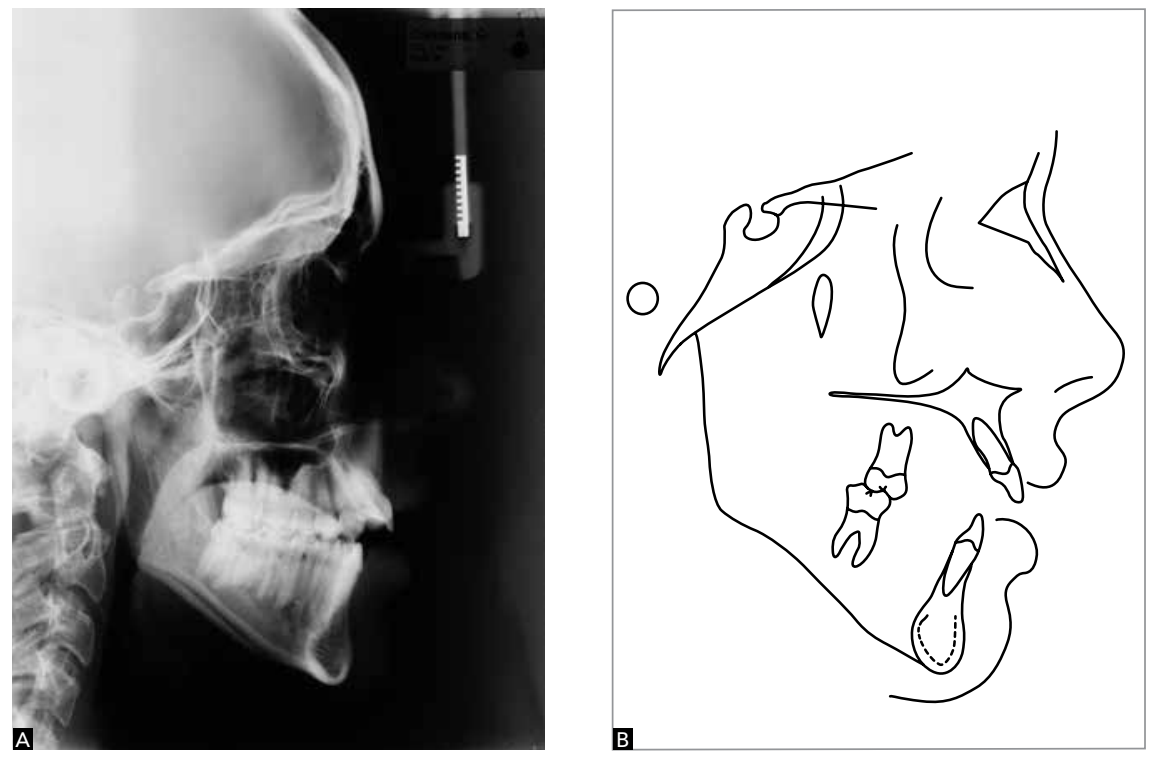

Figure 4 - Initial profile cephalometric radiograph (A) and initial cephalometric tracing (B) 


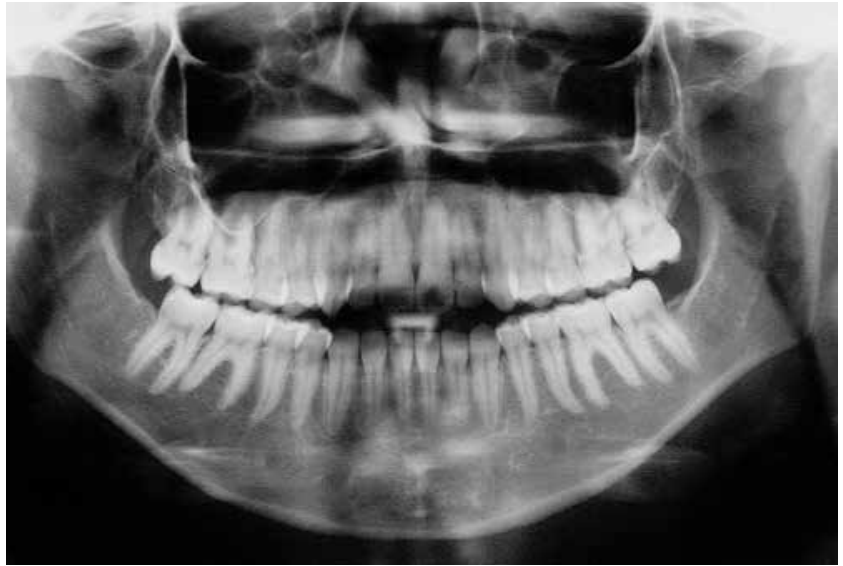

Figure 5 - Initial panoramic radiograph.

bar was installed for anchorage control. On the upper arch, alignment and leveling were performed on three segments: On teeth \#13 to \#17, \#12 to \#22 and \#23 to \#27. All segments began with 0.014-in NiTi wire, followed by $0.016,0.018$ and 0.020 -in stainless steel wires, and, at last, $0.018 \times 0.025$-in stainless steel wire. At this phase, an extrusion arch was placed for the upper incisors, with a $0.017 \times 0.025$-in TMA wire coming out from the auxiliary tubes of the upper first molars, bypassing, being superimposed on the region of the upper incisors and being activated for extrusion. After leveling, the upper occlusal plan was realigned with a continuous arch prior to mass space closure conventional mechanics, using stainless steel $0.018 \mathrm{x}$ 0.025-in and $0.019 \times 0.025$-in archwires, with Bull loops between teeth \#13 and \#14, and \#23 and \#24.

At treatment finishing, stainless steel $0.019 \times 0.025$-in rectangular archwires were used with first, second and third order bends individualized as necessary. In the lower arch, alignment and leveling were initiated with NiTi archwire 0.014 -in, followed by 0.014 to 0.020 -in SS archwires with first and second order bends. Stainless steel $0.019 \times 0.025$-in rectangular finishing archwires, coordinated, with first, second and third order bends individualized as necessary, were used next.

As retention protocol, a fixed bar was installed between teeth \#11 and \# 21 (Bond a Braid) and a full removable upper plate was installed with stainless steel 0.032-in archwire. In the lower arch, an intercanine fixed bar was installed with 0.032-in Twist Flex archwire. The patient needed speech monitoring for six months, starting one month before the removal of the fixed appliances. Occlusal adjustments were performed in three moments: at the finishing phase, six months and one year after removal of the appliance. Furthermore, anatomic recontouring of the upper incisors was performed in addition to gingival plasty carried out on the posterior teeth for better dental exposure and, consequently, better esthetics.

\section{OBTAINED RESULTS}

After orthodontic finishing, exams were performed in two moments: At final phase (Figs 6 and 7) and after two years of control (Figs 8 and 9). Improvement in lip seal, smile harmony with good visualization of the posterior teeth and good exposition of the incisors (gingival plasty was extremely relevant for the beauty of the smile) and mild alteration in the upper lip (ULLine $\mathrm{S}=-1 \mathrm{~mm}$ after treatment and $-1.5 \mathrm{~mm}$ after two years of control) were observed.

The molars finished in Class II relationship, as expected, but with canines in key of occlusion. The anterior open bite was corrected and the results were maintained after the control period. Improvement in midline deviation ( with slight deviation), correction of the overjet (1 mm final and after two years) and in the upper arch shape (Figs 6 to 9) were observed.

Vertically, the patient presented the same characteristics, as expected, since an exclusively orthodontic treatment was chosen. On the anteroposterior direction, there was slight improvement in the ANB angle ( $3^{\circ}$ initial, $2^{\circ}$ final and after two years of stability). Cephalometrically, the upper incisors were retroclined and retracted $\left(1 . \mathrm{NA}=13^{\circ}\right.$ and $1-\mathrm{NA}=3.5 \mathrm{~mm}$, maintained after two years of control) (Figs 10 and 11, Table 1).

On assessing the final panoramic radiograph, good root parallelism after space closure was observed. Such parallelism was preserved after two years of control and root lengths underwent minor alterations, only (Figs 12 and 13).

Interpretation of the cephalometric superimpositions demonstrated improvement in facial profile and lip position, which promoted not only a better seal, but also mild alteration of the upper lip and correction of the overjet and overbite. Partial assessment of the maxilla demonstrated significant retroclination, retraction and extrusion of the upper incisors, in addition to mesialization of the upper molars due to anchorage loss. Partial assessment of the mandible did not demonstrate any significant alteration (Fig 14). 

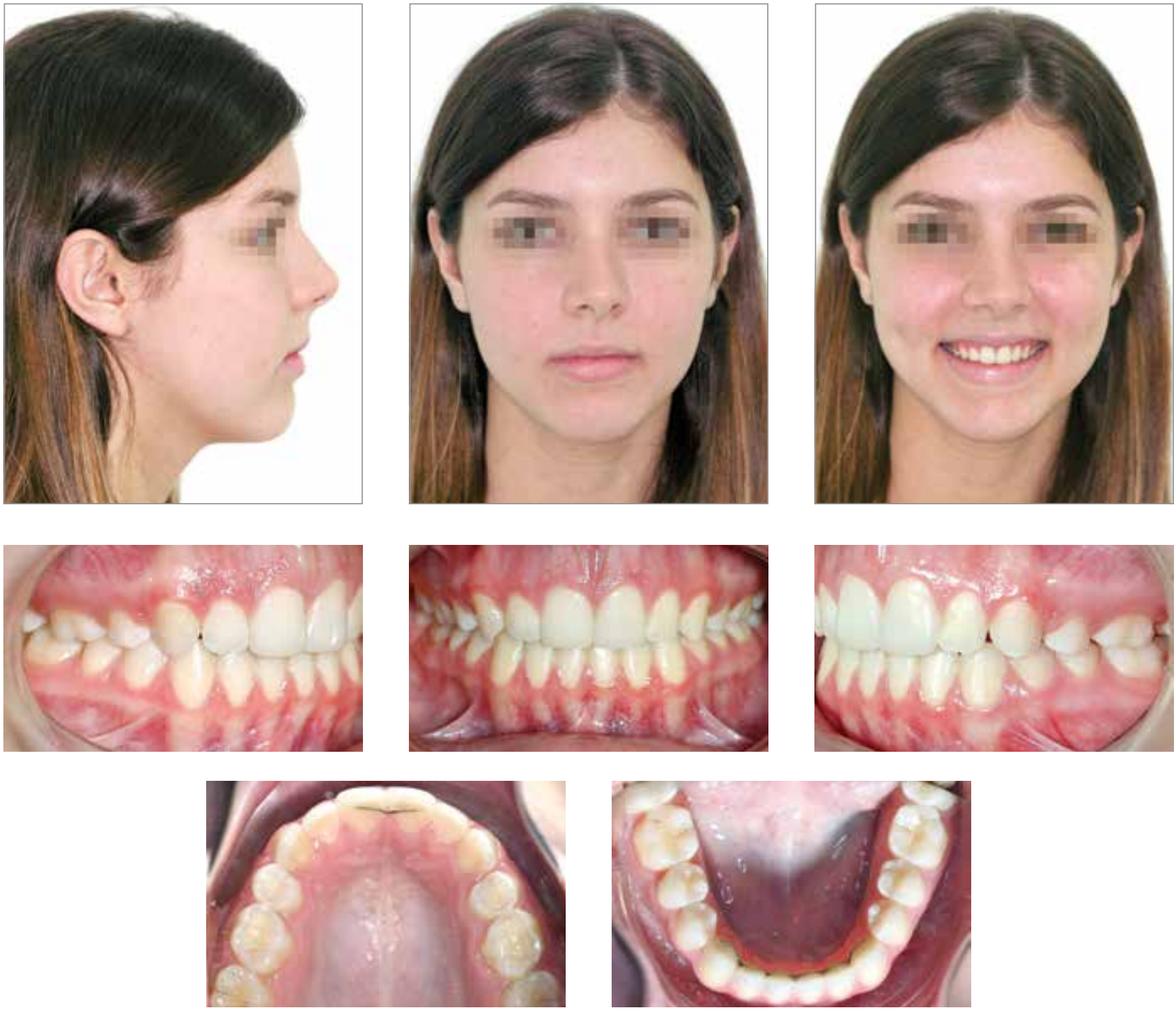

Figure 6 - Final facial and intraoral photographs.
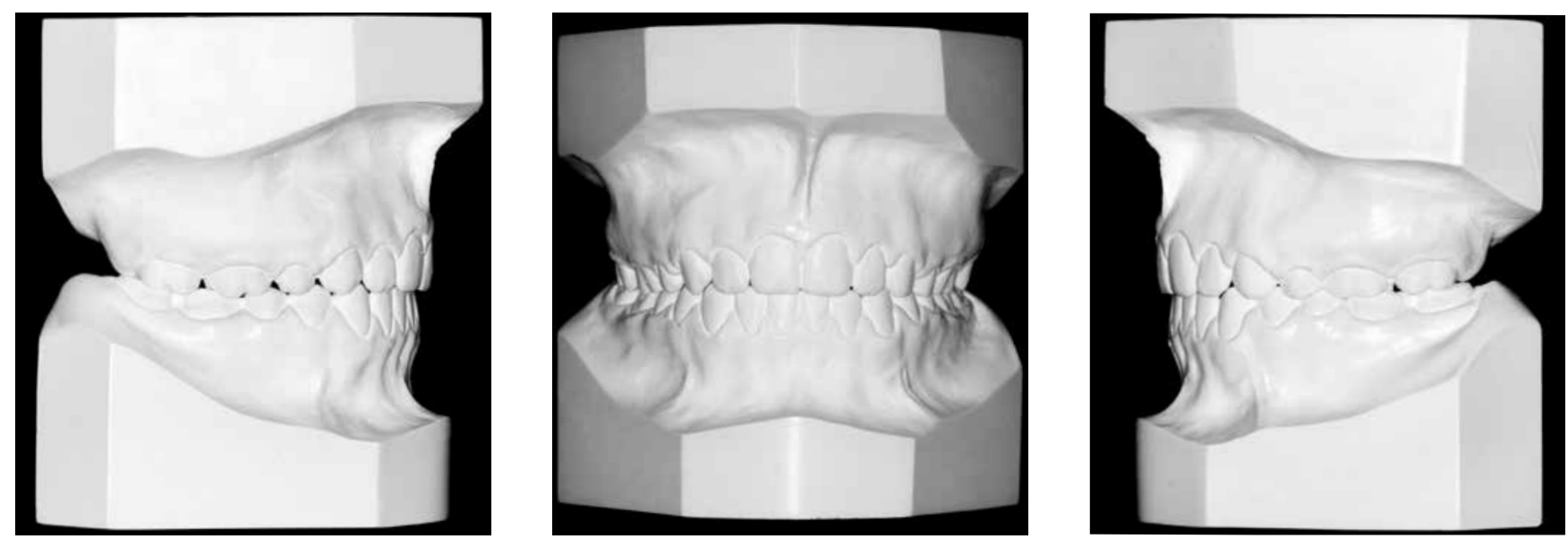

Figure 7 - Final casts. 

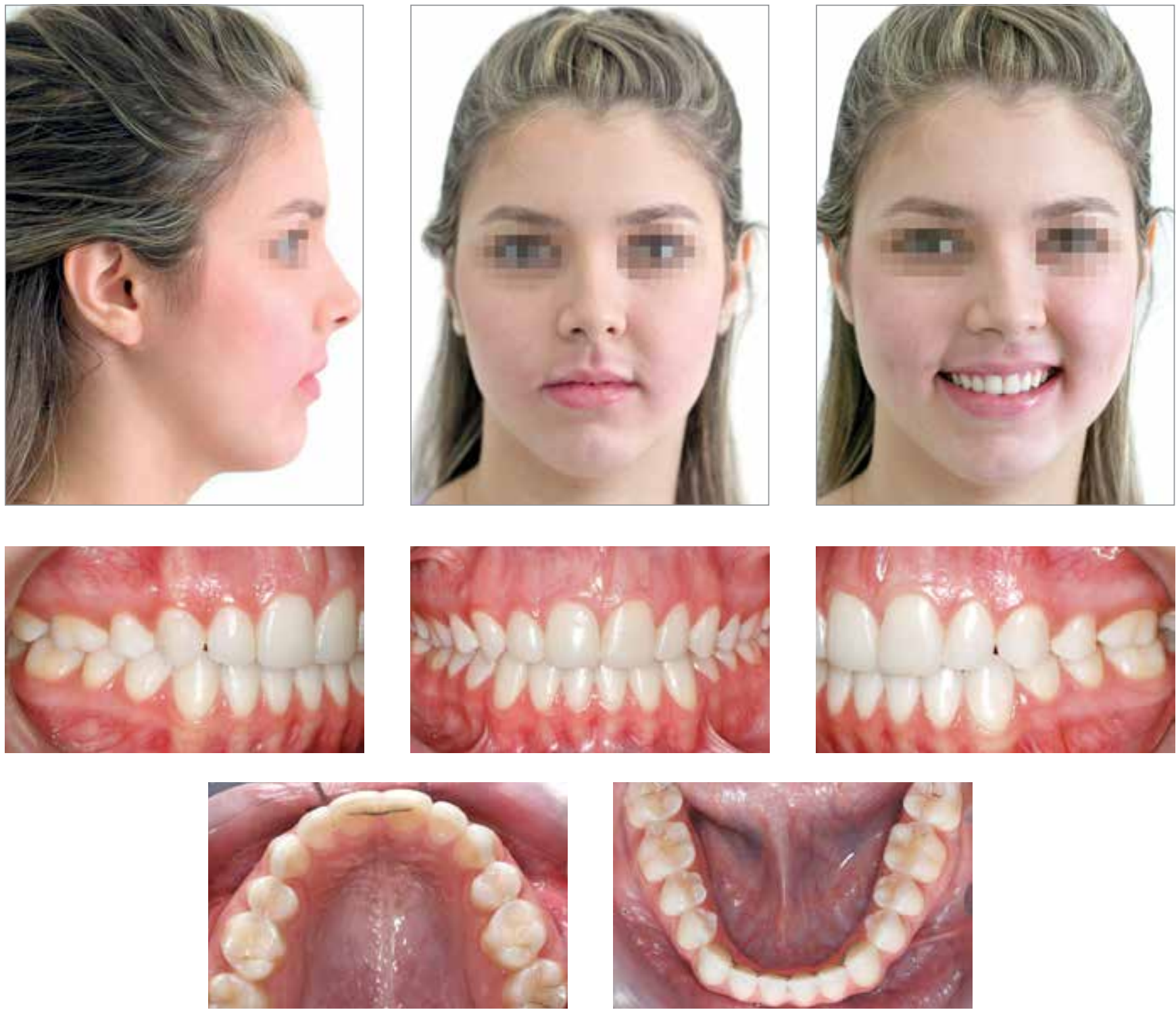

Figure 8 - Facial and intraoral photographs of control after two years.
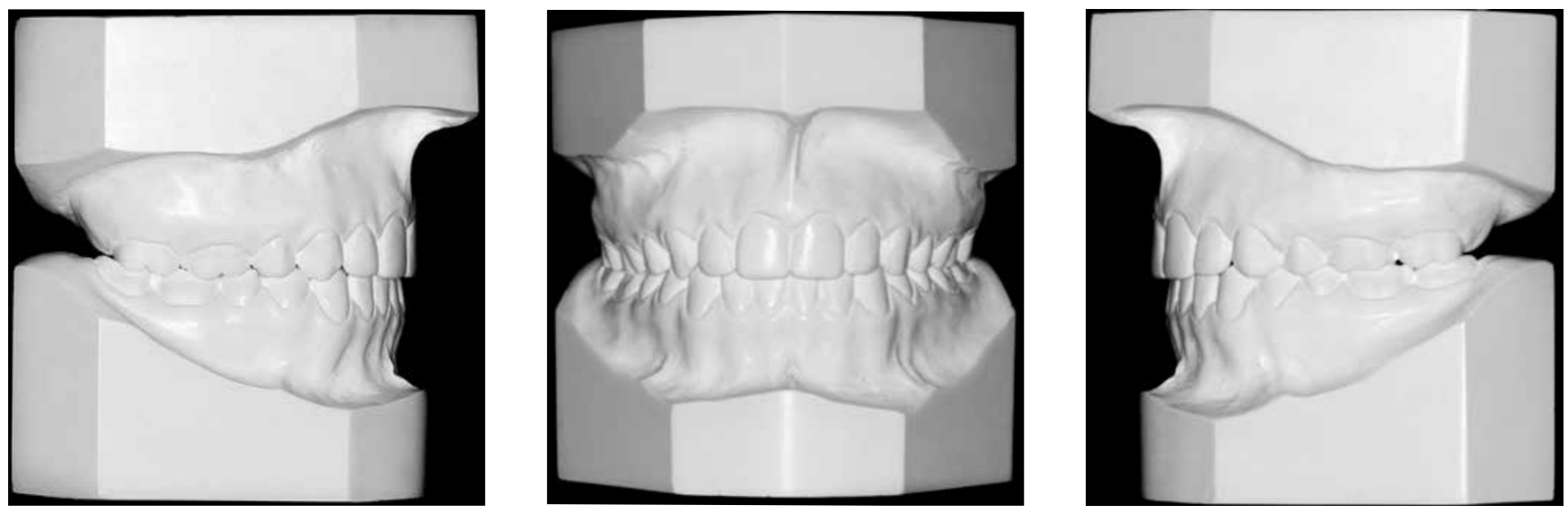

Figure 9 - Control casts after two years. 

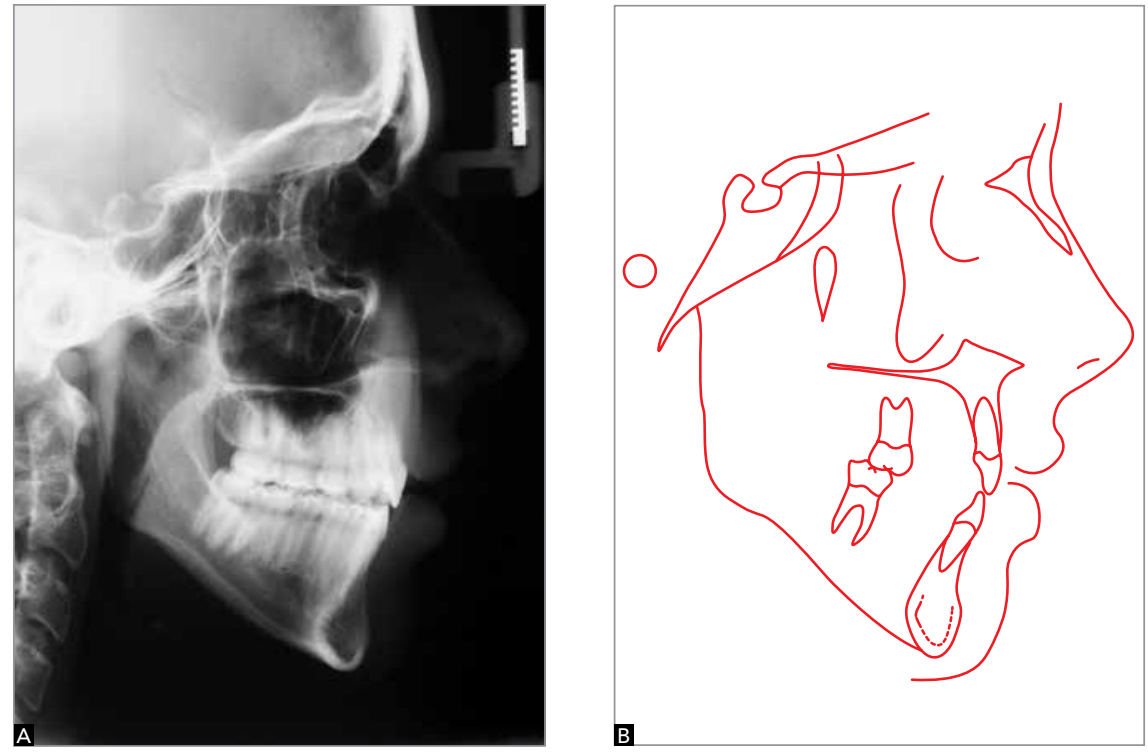

Figure 10 - Final profile cephalometric radiograph (A) and cephalometric tracing (B)
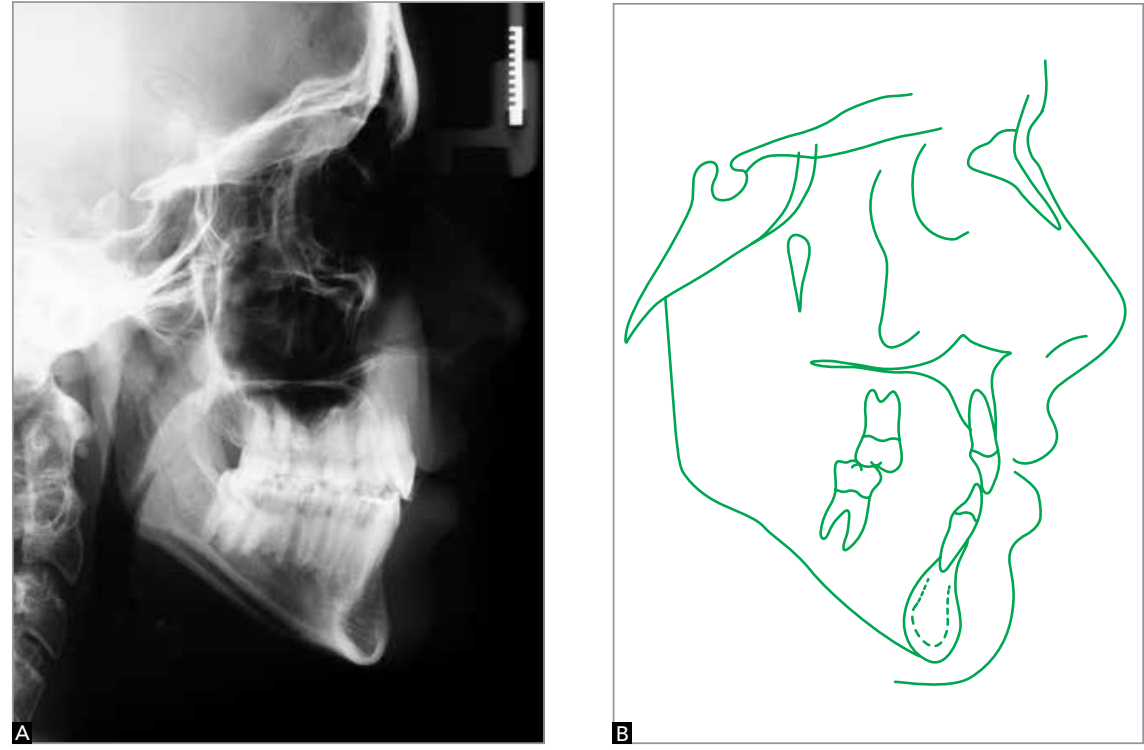

Figure 11 - Cephalometric radiograph (A) and profile cephalometric tracing (B) of control after two years.

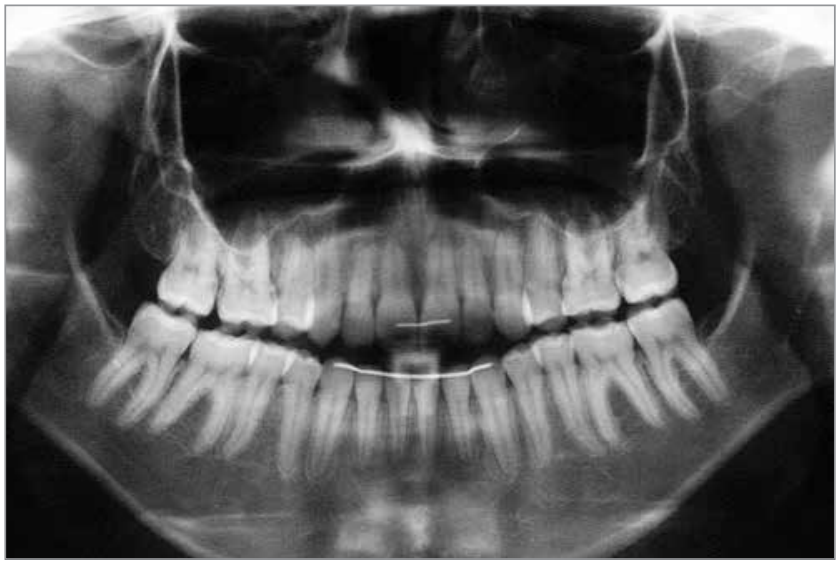

Figure 12 - Final panoramic radiograph.

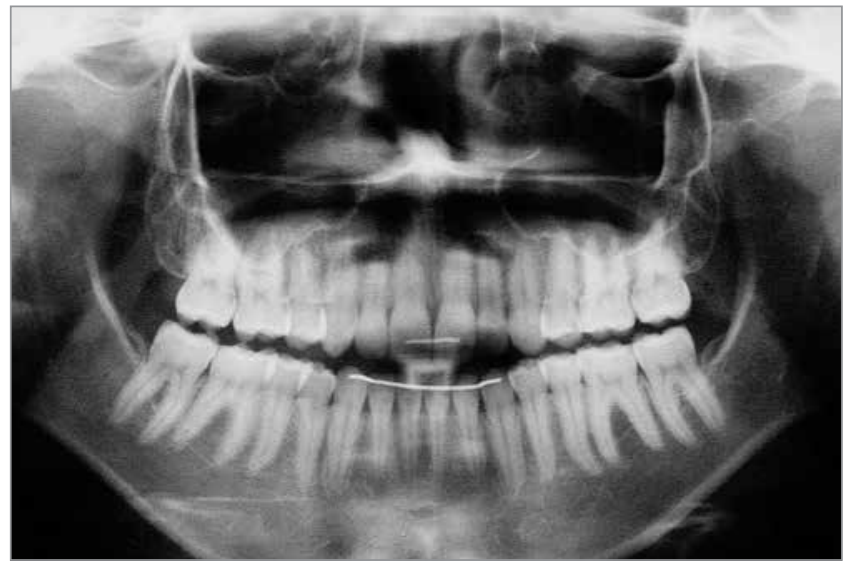

Figure 13 - Panoramic radiograph of control after two years 

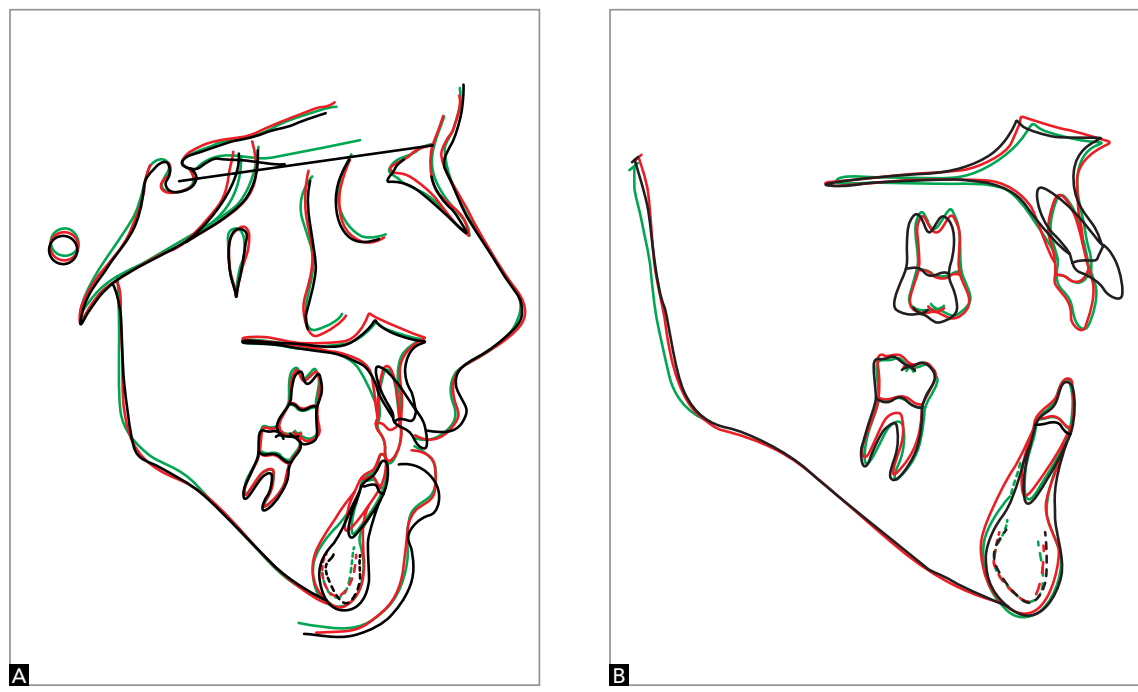

Figure 14 - Total (A) and partial (B) superimpositions of initial tracing (black), final tracing (red), and tracing of control after two years (green).

Table 1 - Cephalometric measurement summary

\begin{tabular}{|c|c|c|c|c|c|c|c|}
\hline & Mea & & Normal & A & B & A/B diff. & Control \\
\hline \multirow{8}{*}{ Skeletal pattern } & SNA & (Steiner) & $82^{\circ}$ & $75^{\circ}$ & $73.5^{\circ}$ & $1.5^{\circ}$ & $73^{\circ}$ \\
\hline & SNB & (Steiner) & $80^{\circ}$ & $72^{\circ}$ & $71.5^{\circ}$ & $0.5^{\circ}$ & $71^{\circ}$ \\
\hline & ANB & (Steiner) & $2^{\circ}$ & $3^{\circ}$ & $2^{\circ}$ & $1^{\circ}$ & $2^{\circ}$ \\
\hline & Facial angle & (Downs) & $0^{\circ}$ & $2^{\circ}$ & $2^{\circ}$ & $0^{\circ}$ & $2^{\circ}$ \\
\hline & $Y$ axis & (Downs) & $59^{\circ}$ & $66^{\circ}$ & $67^{\circ}$ & $1^{\circ}$ & $67^{\circ}$ \\
\hline & Facial angle & (Downs) & $87^{\circ}$ & $83^{\circ}$ & $82.5^{\circ}$ & $0.5^{\circ}$ & $82^{\circ}$ \\
\hline & SN-GoGn & (Steiner) & $32^{\circ}$ & $45^{\circ}$ & $45^{\circ}$ & $0^{\circ}$ & $45^{\circ}$ \\
\hline & FMA & (Tweed) & $25^{\circ}$ & $36^{\circ}$ & $36.5^{\circ}$ & $0.5^{\circ}$ & $37^{\circ}$ \\
\hline \multirow{7}{*}{ Dental pattern } & IMPA & (Tweed) & $90^{\circ}$ & $76^{\circ}$ & $78^{\circ}$ & $2^{\circ}$ & $77.5^{\circ}$ \\
\hline & 1.NA (degrees) & (Steiner) & $22^{\circ}$ & $35.5^{\circ}$ & $13^{\circ}$ & $22.5^{\circ}$ & $13^{\circ}$ \\
\hline & $\underline{1}-\mathrm{NA}(\mathrm{mm})$ & (Steiner) & $4 \mathrm{~mm}$ & $9 \mathrm{~mm}$ & $3.5 \mathrm{~mm}$ & $5.5 \mathrm{~mm}$ & $4 \mathrm{~mm}$ \\
\hline & I.NB (degrees) & (Steiner) & $25^{\circ}$ & $16^{\circ}$ & $16^{\circ}$ & $0^{\circ}$ & $16^{\circ}$ \\
\hline & I-NB (mm) & (Steiner) & $4 \mathrm{~mm}$ & $3 \mathrm{~mm}$ & $3.5 \mathrm{~mm}$ & $0.5 \mathrm{~mm}$ & 4 \\
\hline & $\frac{1}{1}$ - Interincisal angle & (Downs) & $130^{\circ}$ & $127^{\circ}$ & $150^{\circ}$ & $23^{\circ}$ & $150^{\circ}$ \\
\hline & I-APo (mm) & (Ricketts) & $1 \mathrm{~mm}$ & $-1 \mathrm{~mm}$ & $0 \mathrm{~mm}$ & $1 \mathrm{~mm}$ & $0 \mathrm{~mm}$ \\
\hline \multirow{2}{*}{ Profile } & Upper lip - S line & (Steiner) & $0 \mathrm{~mm}$ & $-0.5 \mathrm{~mm}$ & $-1 \mathrm{~mm}$ & $0.5 \mathrm{~mm}$ & $-1.5 \mathrm{~mm}$ \\
\hline & Lower lip - S line & (Steiner) & $0 \mathrm{~mm}$ & $0 \mathrm{~mm}$ & $0.5 \mathrm{~mm}$ & $0.5 \mathrm{~mm}$ & $0 \mathrm{~mm}$ \\
\hline
\end{tabular}

\section{FINAL CONSIDERATIONS}

The results were satisfactory and the objectives were achieved. It should be highlighted that in this treatment, orthognathic surgery was considered, but discarded by the patient as well as by her parents. Additionally, the final smile was pleasant and expressive, with good dental exposure, correction of anterior open bite and overjet, with good stability after a two-year follow-up. The patient was very glad, since treatment exceeded her expectations as well as her family's. It is worth emphasizing the importance of a multidisciplinary approach involving Cosmetic Dentistry and Periodontics, for the success of the treatment.
REFERENCES

1. Proffit WR, Phillips C, Douvartzidis N. A comparison of outcomes of orthodontic and surgical-orthodontic treatment of Class II malocclusion in adults. Am J Orthod Dentofacial Orthop. 1992:101(6):556-65.

2. Proffit WR. Ortodontia contemporânea. 3a ed. Rio de Janeiro: Guanabara Koogan; 2002

3. Mihalik CA, Proffit WR, Phillips C. Long-term follow-up of Class II adults treated with orthodontic camouflage: a comparison with orthognathic surgery outcomes. Am J Orthod Dentofacial Orthop. 2003;123(3):266-78.

4. Cal-Neto JP, Quintão CC, de Menezes LM, Almeida MA. Severe anterior open-bite malocclusion. orthognathic surgery or several years of orthodontics? Angle Orthod. 2006:76(4):728-33.

5. Janson G, Valarelli FP, Beltrão RTS, Freitas MR, Henriques JFC. Stability of anterior open-bite extraction and nonextraction treatment in the permanent dentition. Am J Orthod Dentofacial Orthop. 2006:129(6):768-74. 